\begin{tabular}{cc}
\hline Jurnal Einstein 4 (3) (2016): 22-30 \\
Available online http://jurnal.unimed.ac.id/2012/index.php/einstein
\end{tabular}

\title{
Analisis Rongga Pada Aspal Iran Pen 80/100 Termodifikasi Dengan Karet Alam (Natural Rubber) Pada Campuran Asphalt Concrete - Wearing Course (AC-WC)
}

\section{Cavity Analysis On Iranian Asphalt Pen 80/100 Modified With Natural Rubber On Asphalt Concrete - Wearing Course ( $A C$-WC)}

\author{
Alkhafi Maas Siregar, Winsyahputra Ritonga, Santri Arunika* \\ Jurusan Fisika, Fakultas Matematika dan Ilmu Pengetahuan Alam, Universitas \\ Negeri Medan, Indonesia \\ Diterima Agustus 2016; Disetujui September 2016; Dipublikasikan Nopember 2016
}

\begin{abstract}
This study is aimed to determine the effect of natural rubber (NR) in asphalt bitumen to modified its characteristics and the effect of addition of $N R$ to modified asphalt on its Void in the Mix (VIM), Voids in mineral aggregate (VMA), and Voids Filled with Asphalt (VFA) value. The VIM was set on range of 3 - to $5.5 \%$. The VMA was bounded minimum at $15 \%$. While the VFA rated at a minimum of $65 \%$. Sample preparation is done with natural rubber refluxing with xylene and then inserted into the asphalt that has been heated and then coupled with acrylic acid and benzoyl peroxide compatibilizer. Sample have met the test requirements in each sample covering, penetration test, softening point, density, ductilityt, and weight loss. Volumetric value on VIM by adding $0 \mathrm{phr}, 1 \mathrm{phr}, 2 \mathrm{phr}, 3 \mathrm{phr}$, and $4 \mathrm{phr}$ of $\mathrm{NR}$ on asphalt is $5.275 \%$, $5.048 \%, 5.383 \%, 6.192 \%$, and $6.902 \%$. VMA value of $19.110 \%, 19.010 \%, 19.357 \%$, $20.033 \%$ and $20.673 \%$. VFA value on asphalt modified is $72.396 \%, 73.447 \%, 72.189 \%$, $69.089 \%$ and $66.616 \%$. It can be concluded that there is the effect of the addition of NR modified asphalt for asphalt characteristics and volumetric properties of asphalt.
\end{abstract}

Keywords: Iranian asphalt, Natural Rubber, VIM, VMA, VFA

\begin{abstract}
ABSTRAK
Penelitian ini bertujuan untuk mengetahui pengaruh penambahan karet alam pada aspal termodifikasi terhadap karakteristik aspal pen 80/100 dan pengaruh
\end{abstract}


penambahan karet alam pada aspal termodifikasi pada nilai Void in the Mix (VIM), Void in Mineral Agregate (VMA), dan Void Filled with Asphalt (VFA). Rongga dalam campuran / Voids in Mix (VIM) diberi rentang antara 3-5,5\%. Rongga dalam agregat (VMA) dibatasi minimal sebesar 15\%. Sedangkan rongga terisi aspal (VFA) diberi nilai minimal sebesar 65\%. Pembuatan sampel dilakukan dengan merefluks karet alam dengan xylene kemudian dimasukkan ke dalam aspal yang telah dipanaskan lalu ditambah dengan asam akrilat dan compatibilizer benzoil peroksida. Sampel memenuhi uji persyaratan aspal pada masing-masing sampel meliputi, uji penetrasi, titik lembek, berat jenis, daktilitas, dan kehilangan berat. Nilai volumetrik berupa VIM pada penambahan $0 \mathrm{phr}, 1 \mathrm{phr}, 2 \mathrm{phr}, 3 \mathrm{phr}$, dan $4 \mathrm{phr}$ NR pada aspal adalah $5,275 \%, 5,048 \%, 5,383 \%, 6,192 \%$, dan 6,902\%. Nilai VMA sebesar 19,110\%, 19,010\%, $19,357 \%, 20,033 \%$, dan 20,673\%. Sedangkan nilai VFA pada aspal termodifikasi sebesar $72,396 \%, 73,447 \%, 72,189 \%, 69,089 \%$, dan 66,616\%. Kesimpulan dari penelitian ini adalah terdapat pengaruh penambahan karet alam pada aspal termodifikasi terhadap karakteristik aspal dan sifat volumetrik aspal.

Kata kunci: Iran, Karet Alam, VIM, VMA, VFA

How to Cite: Alkhafi Maas Siregar, Winsyahputra Ritonga, Santri Arunika, (2016), Analisis Rongga Pada Aspal Iran Pen 80/100 Termodifikasi Dengan Karet Alam (Natural Rubber) Pada Campuran Asphalt Concrete - Wearing Course (AC-WC), Jurnal Einsten Prodi Fisika FMIPA Unimed, 4 (3) : 22-30. 
Alkhafi Maas Siregar, Winsyahputra Ritonga, Santri Arunika, Analisis Rongga Pada Aspal Iran Pen 80/100 Termodifikasi Dengan Karet Alam (Natural Rubber) Pada Campuran Asphalt Concrete - Wearing Course (AC-WC)

\section{PENDAHULUAN}

Jalan merupakan prasarana angkutan darat yang sangat penting dalam memperlancar kegiatan hubungan perekonomian, baik antara satu kota dengan kota lainnya, maupun antara kota dengan desa dan antara satu desa dengan desa lainnya. Kondisi jalan yang baik akan memudahkan mobilitas penduduk dalam mengadakan hubungan perekonomian dan kegiatan sosial lainnya (Sari, 2003). Bila kondisi jalan rusak, salah satu akibatnya adalah kemacetan lalu lintas bahkan tidak jarang menjadi penyebab terjadinya kecelakaan lalu lintas. Hal ini tentu akan menghambat kegiatan perekonomian dan kegiatan sosial masyarakat (Ing, dkk., 2013).

Kerusakan jalan di Indonesia umumnya disebabkan oleh pembebanan yang terjadi berlebihan (overload) atau disebabkan oleh Physical Damage Factor (PDF) berlebih, banyaknya arus kendaraan yang lewat (repetisi beban) sebagai akibat pertumbuhan jumlah kendaraan yang cepat terutama kendaraan komersial dan perubahan lingkungan (pengaruh suhu), atau oleh karena fungsi drainase yang kurang baik (akibat ukuran pori aspal yang besar) (Fatmawati, 2011).

Ukuran pori-pori mempengaruhi cepat lambatnya aliran air. Air yang melewati pori-pori akan membawa partikel-partikel aspal sehingga partikelpartikel aspal yang terbawa merupakan pembesaran ruang pori diantara butiran aspal. Hal ini akan menyebabkan debit air yang mengalir semakin besar dan volume aspal akan berkurang. Berkurangnya volume aspal akan mempengaruhi kondisi jalan disekitarnya, terutama terbentuknya banyak lubang (Harseno dan Daryanto, 2008).

Akibat besarnya ukuran pori aspal ini, air akan mudah tergenang di atas permukaan aspal. Genangan air dapat mengakibatkan terjadinya kerusakan jalan dikarenakan air dapat melonggarkan ikatan antara agregat dengan aspal. Saat ikatan aspal dan agregat longgar karena air, kendaraan yang lewat akan memberi beban yang menimbulkan retak atau kerusakan jalan lainnya. Dari hal tersebut dapat dikatakan bahwa (genangan) air menyebabkan kerusakan atau mengurangi keawetan konstruksi jalan dengan perkerasan aspal (Sulistiyatno, dkk., 2012).

Rongga terisi aspal (VFA) adalah persen rongga yang terdapat diantara partikel agregat (VMA) yang terisi oleh aspal, tidak termasuk aspal yang diserap oleh agregat.VIM (Void In the mix) adalah volume pori yang tersisa setelah campuran beton aspal dipadatkan. VIM dibutuhkan untuk tempat bergesernya butir-butir agregat akibat pemadatan tambahan yang terjadi oleh repetisi beban lalu lintas, atau tempat aspal menjadi lunak/ mengembang akibat meningkatnya temperatur. VIM yang terlalu besar akan mengakibatkan beton aspal kurang kedap air, sehingga berakibat meningkatnya proses oksidasi aspal yang dapat mempercepat penuaan aspal dan menurunkan sifat durabilitas. VIM yang terlalu kecil akan berakibat perkerasan mengalami bleeding jika mengalami peningkatan temperatur (Rianung, 2007).

Material baru yang memungkinkan dicoba untuk dijadikan campuran dalam pembuatan aspal adalah karet alam (Natural Rubber). Sifat karet yang elastis diharapkan dapat menambah kekuatan aspal jalan raya (Chusna, 2002).

\section{METODE PENELITIAN}

\section{Bahan:}

Aspal, Karet Alam (Natural Rubber), Asam Akrilat, BPO (Benzoil Peroksida), Xylene. 
Metode :

Adapun metode penelitian untuk pengujian rongga pada aspal termodifikasi meliputi :

1. Pembuatan Aspal Modifikasi.

1) Mempersiapkan Alat dan bahan yang akan digunakan.

2) Mengambil Sampel NR lalu memotong hingga berukuran $2 \mathrm{~cm}$.

3) Mengeringkan sampel NR dengan suhu $60^{\circ} \mathrm{C}$ selama 3 hari didalam oven.

4) Merefluks karet alam dengan labu leher 3 yang terdiri campuran Xylene dan karet alam sambil dipanaskan dan diaduk pada suhu $120^{\circ} \mathrm{C}$ dan $180 \mathrm{rpm}$ selama 30 menit. Sampai berbentuk seperti gel.

5) Sebanyak $2 \mathrm{~kg}$ aspal dimasukkan ke dalam Panci.

6) Menuangkan hasil refluks kedalam Aspal sebanyak $2 \mathrm{~kg}$ yang telah disediakan.

7) Memanaskan Aspal dengan menggunakan heater Yang telah ditambah dengan hasil refluks NR, ditambah dengan Asam Akrilat dan Benzoil Peroksida dengan variasi jumlah yang berbeda sesuai komposisi ke dalam aspal tersebut sambil dipanaskan dan diaduk dengan mixer pada suhu $90{ }^{\circ} \mathrm{C}$ dan 180 rpm selama 30 menit.

8) Selanjutnya setelah selesai sampel didinginkan selama 3 hari agar campuran menjadi padat kembali.

9) Perlakuan yang sama juga dilakukan variasi yang yang lain.

\section{Pengujian Sifat Fisik Persyaratan Aspal}

Pengujian terhadap sampel dilakukan dalam bentuk pengujian sifat fisik aspal yang meliputi uji penetrasi, uji titik lembek, uji daktilitas, uji berat jenis dan uji penurunan/kehilangan berat aspal yang telah termodifikasi menurut SNI.

\section{Pengujian Sifat Volumetrik Aspal}

Pengujian volumetrik benda uji mengacu pada SNI 06-2489-1991, terdiri atas pembuatan benda uji dan pengujian volumetrik benda uji.

\section{A. Pembuatan Benda Uji}

1) Agregat dikeringkan didalam oven pada suhu $110^{\circ} \mathrm{C}$ sekurangkurangnya selama empat jam. Setelah kering agregat dipisahkan sesuai dengan ukurannya dengan menggunakan ayakan.

2) Bahan untuk setiap benda uji yang diperlukan yaitu agregat sebanyak \pm 1128 gram sehingga menghasilkan tinggi benda uji kira-kira $63,5 \mathrm{~mm} \pm 1 \mathrm{~mm}$.

3) Agregat ditimbang sesuai dengan persen tertahan setiap ukuran ayakan yang dihitung berdasarkan gradasi rencana agregat campuran.

4) Panci pencampur dipanaskan beserta agregat sampai suhu 90 ${ }^{0} \mathrm{C}$. Aspal yang sudah mencapai tingkat kekentalan sebanyak yang dibutuhkan dituangkan ke dalam agregat yang sudah dipanaskan tersebut, kemudian aduklah dengan cepat, pada suhu $145^{\circ} \mathrm{C}$ dan agregat terselimuti aspal secara merata..

5) Hasil campuran dimasukan ke dalam cetakan dan melakukan pemadatan dengan menumbuk specimen dengan jumlah tumbukan sebanyak 75 kali tumbukan .

6) Tumbukan dilakukan dengan tinggi jatuh 457,2 $\mathrm{mm}$ dan selama pemadatan harus diperhatikan agar kedudukan sumbu palu pemadat selalu tegak lurus pada alas cetakan.

7) Pelat alas dilepaskan berikut leher sambung dari cetakan benda uji, kemudian cetakan yang berisi benda uji dibalikkan dan pasang kembali pelat alas berikut leher sambung pada cetakan yang dibalikkan tadi. Lakukan 
Alkhafi Maas Siregar, Winsyahputra Ritonga, Santri Arunika, Analisis Rongga Pada Aspal Iran Pen 80/100 Termodifikasi Dengan Karet Alam (Natural Rubber) Pada Campuran Asphalt Concrete - Wearing Course (AC-WC)

penumbukan lagi dengan jumlah yang sama.

8) Benda uji dikeluarkan atau spesimen Marshall dari mold dengan hati-hati dan kemudian letakan spesimen permukaan yang rata dan biarkan sampai benar-benar dingin. Sebaiknya didiamkan pada suhu ruang selama 24 jam.

\section{B. Perhitungan Nilai Volumetrik Benda Uji}

Prosedur pengujian mengikuti langkah-langkah berikut :

1) Setelah benda uji didinginkan, benda uji dikeringkan (dalam suhu ruangan);

2) Benda uji dibersihkan dari kotoran yang menempel menggunakan kuas;

3) Memberikan penanda pada empat sisi benda uji menggunakan correction pen pada empat sisi yang berbeda;

4) Mengukur tebal benda uji pada keempat sisi yang telah diberi tanda pada langkah menggunakan jangka sorong.

5) Menimbang masing-masing benda uji (sebagai berat kering);

6) Memasukkan benda uji ke dalam bak perendaman \pm 30 menit;

7) Mengatur timbangan untuk menimbang benda uji dalam air;

8) Memasukkan benda uji ke dalam air (bagian dari timbangan) dan catat hasil pengukuran sebagai berat benda uji dalam air;

9) Mengeluarkan benda uji dari dalam air kemudian keringkan benda uji menggunakan kain.

10) Menimbang kembali benda uji, catat sebagai berat benda uji SSD.

11) Melakukan perhitungan persentase rongga aspal (VIM, VMA, dan VFA).

\section{HASIL DAN PEMBAHASAN}

\section{A. Hasil Penelitian}

\section{Pengujian Sifat Fisik Aspal Modifikasi}

Dari keseluruhan persyaratan sifat fisik aspal, yang dapat dilakukan adalah sebanyak 5 (lima) parameter.

\section{Tabel 1.1 Sifat Fisik Aspal Modifikasi}

\begin{tabular}{|c|c|c|c|c|c|c|c|}
\hline \multirow[b]{2}{*}{ No } & \multirow[b]{2}{*}{ Jenis Pengujian } & \multirow[b]{2}{*}{ Satuan } & \multicolumn{5}{|c|}{ Hasil } \\
\hline & & & $\begin{array}{c}\text { Aspal } \\
+0 \text { phr } \\
\mathrm{KA}+5 \\
\text { ml } \\
\mathrm{AA}^{+} \\
0,336 \\
\text { gr BPO }\end{array}$ & $\begin{array}{c}\text { Aspal } \\
+20 \\
\text { phr } \\
\mathrm{KA}+5 \\
\mathrm{ml} \\
\mathrm{AA}+ \\
0,336 \\
\text { gr BPO }\end{array}$ & $\begin{array}{c}\text { Aspal } \\
+40 \\
\text { phr } \\
\mathrm{KA}+5 \\
\mathrm{ml} \\
\mathrm{AA}+ \\
0,336 \\
\mathrm{~g} \text { BPO }\end{array}$ & $\begin{array}{c}\text { Aspal } \\
+60 \\
\text { phr } \\
\mathrm{KA}+5 \\
\mathrm{ml} \\
\mathrm{AA}+ \\
0,336 \\
\text { gr BPO }\end{array}$ & $\begin{array}{c}\text { Aspal } \\
+80 \\
\text { phr } \\
\mathrm{KA}+5 \\
\mathrm{ml} \\
\mathrm{AA}+ \\
0,336 \\
\text { gr BPO }\end{array}$ \\
\hline 1 & $\begin{array}{l}\text { Penetrasi, } 25 \text { 'C; } \\
100 \text { gr; } 5 \text { dctik; }\end{array}$ & $\mathrm{mm}$ & 85 & 217 & 234,5 & 256,25 & 274,5 \\
\hline 2 & Titik Lembek & ${ }^{\circ} \mathrm{C}$ & 49,75 & 48 & 47,25 & 47,75 & 46 \\
\hline 3 & Daktilitas $25^{\circ} \mathrm{C}$ & $\mathrm{cm}$ & 0,2646 & 134 & 152 & 152 & 152 \\
\hline 4 & Berat jenis, & $\mathrm{gr} / \mathrm{ml}$ & 106,5 & 1,0077 & 1,0019 & 1,0030 & 1,0000 \\
\hline 5 & $\begin{array}{l}\text { Penurunan Berat } \\
\text { (dengan TFOT) }\end{array}$ & $\%$ berat & 1,0153 & 0,4329 & 0,6122 & 0,8949 & 0,9153 \\
\hline
\end{tabular}

\section{Pengujian Sifat Volumetrik Aspal Modifikasi}

Hasil penelitian terhadap aspal yang telah ditambah asam akrilat dan benzoil peroksida dapat dilihat pada Tabel 1.2 berikut. Nilai VIM, VMA dan VFA pada aspal termodifikasi dengan penambahan $20 \mathrm{gr}, 40 \mathrm{gr}, 60 \mathrm{gr}$, dan $80 \mathrm{gr}$ memenuhi persyaratan, kecuali nilai VIM pada aspal termodifikasi pada penambahan 60 gr dan 80 gr karet alam yang tidak memenuhi persyaratan, yakni sebesar $6,192 \%$ dan $6,902 \%$ sedangkan nilai VIM yang diizinkan berkisar antara $3-5,5 \%$.

Tabel 1.2 Sifat Volumetrik Aspal Modifikasi

\begin{tabular}{|c|l|c|c|c|c|c|c|}
\hline \multirow{2}{*}{$\begin{array}{c}\text { N } \\
\text { o }\end{array}$} & \multirow{2}{*}{$\begin{array}{c}\text { Jenis } \\
\text { Pengujian }\end{array}$} & \multirow{2}{*}{ Spesifikasi } & \multicolumn{5}{|c|}{ Perlakuan pada Aspal Modifikasi dengan } \\
\cline { 4 - 8 } & & & $\mathbf{0 ~ g r}$ & $\mathbf{2 0}$ gr & $\mathbf{4 0} \mathbf{~ g r}$ & $\mathbf{6 0} \mathbf{~ g r}$ & $\mathbf{8 0} \mathbf{~ g r}$ \\
\hline 1 & VIM (\%) & $3-5,5$ & 5,275 & 5,048 & 5,383 & 6,192 & 6,902 \\
\hline 2 & VMA (\%) & $\min 15$ & 19,110 & 19,010 & 19,357 & 20,033 & 20,673 \\
\hline 3 & VFA (\%) & $\min 65$ & 72,396 & 73,447 & 72.189 & 69,089 & 66,616 \\
\hline
\end{tabular}

\section{Pengujian Penetrasi Aspal}

Gambar 4.1 menunjukkan bahwa semakin tinggi konsentrasi penambahan NR yang dicampurkan pada aspal murni mengakibatkan terjadinya perubahan nilai penetrasi aspal. 


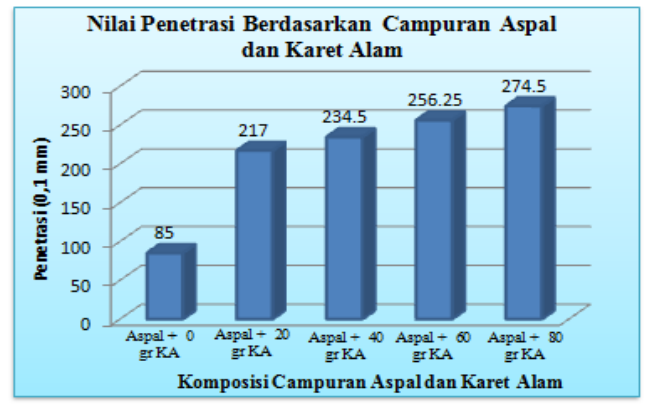

Gambar 4.1 Grafik Hubungan antara Nilai penetrasi dan Campuran Aspal-KA

\section{Pengujian Titik Lembek Aspal}

Gambar 4.2 menunjukkan bahwa nilai titik lembek aspal murni adalah $49,75^{\circ} \mathrm{C}$. Penambahan karet sebanyak 20 gr berdampak pada penurunan nilai titik lembek menjadi $48^{\circ} \mathrm{C}$, penambahan $40 \mathrm{gr}$ karet alam pada aspal juga semakin menurunkan titik lembek aspal menjadi $47,25^{\circ} \mathrm{C}$. Penambahan variasi karet alam sebesar 60 gr meningkatkan nilai titik aspal dari nilai titik lembek pada penambahan $40 \mathrm{gr}$ karet alam menjadi $47,75^{\circ} \mathrm{C}$. Sedangkan penambahan karet alam sebanyak 80 gr merupakan nilai titik lembek yang paling rendah yaitu $46^{\circ} \mathrm{C}$.

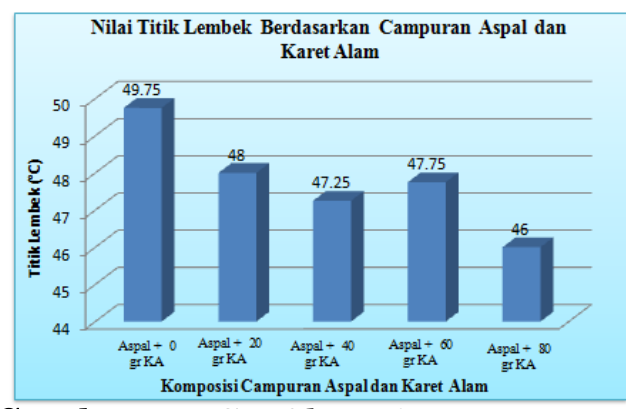

Gambar 4.2 Grafik Hubungan antara

Nilai Titik Lembek dan Campuran Aspal-KA

\section{Pengujian Penurunan/ Kehilangan Berat Aspal}

Gambar 4.3 memperlihatkan bahwa penambahan karet alam mengakibatkan pengaruh terhadap nilai penurunan/ kehilangan berat. Hasil pengujian penurunan/kehilangan berat aspal tertera pada gambar berikut.

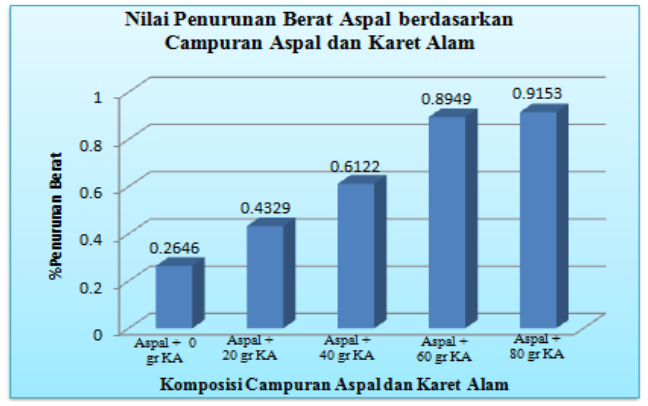

Gambar 4.3 Grafik Hubungan antara Penurunan/Kehilangan Berat Aspal dan Campuran Aspal-KA

\section{Pengujian Daktilitas Aspal}

Nilai daktilitas aspal adalah panjang contoh aspal ketika putus pada saat penarikan dengan kecepatan 5 $\mathrm{cm} /$ menit. Panjang bak pengujian dalam penelitian ini adalah $152 \mathrm{~cm}$. Standar minimal nilai daktilitas yang dipersyaratkan adalah $100 \mathrm{~cm}$. Berikut tertera hasil pengujian daktilitas aspal pada Gambar 4.4 berikut.

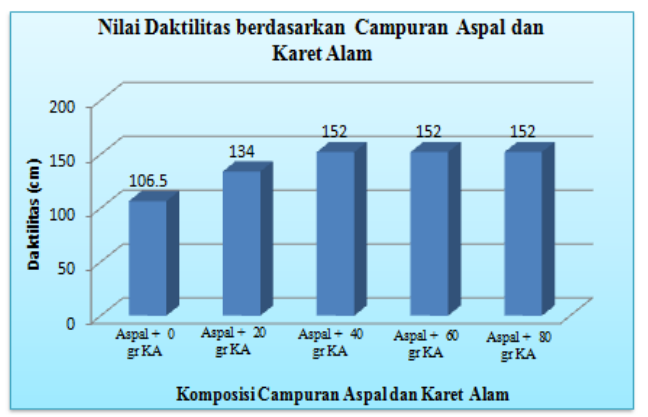

Gambar 4.4 Grafik Hubungan antara Daktilitas Aspal dan Campuran Aspal-KA

\section{Pengujian Berat Jenis Aspal}

Nilai berat jenis aspal murni merupakan berat jenis yang tertinggi, yakni sebesar $1,0153 \mathrm{gr} / \mathrm{ml}$. Terlihat bahwa penambahan karet alam mengakibatkan nilai berat jenis akan semakin rendah. 
Alkhafi Maas Siregar, Winsyahputra Ritonga, Santri Arunika, Analisis Rongga Pada Aspal Iran Pen 80/100 Termodifikasi Dengan Karet Alam (Natural Rubber) Pada Campuran Asphalt Concrete - Wearing Course (AC-WC)

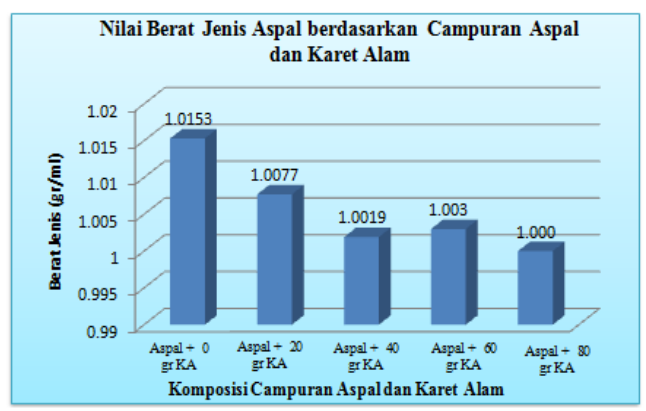

Gambar 4.5 Grafik Hubungan antara

Berat Jenis Aspal dan Campuran Aspal$\mathrm{KA}$

8. Perhitungan Nilai VIM (Void in the Mix), VMA (Voids in Mineral Agregate) dan VFA (Voids Filled with Asphalt)

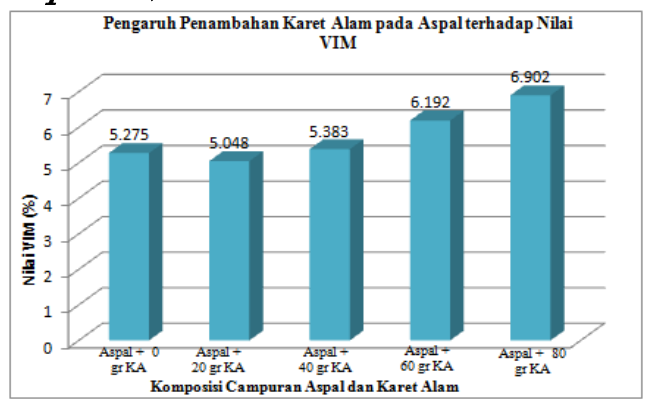

Gambar 4.6 Pengaruh Penambahan Karet Alam pada Aspal terhadap Nilai VIM

Gambar 4.6 menunjukkan bahwa penambahan karet alam pada aspal akan memberikan pengaruh terhadap VIM aspal. Gambar 4.7 menunjukkan bahwa penambahan karet alam pada aspal akan memberikan pengaruh terhadap VMA aspal.

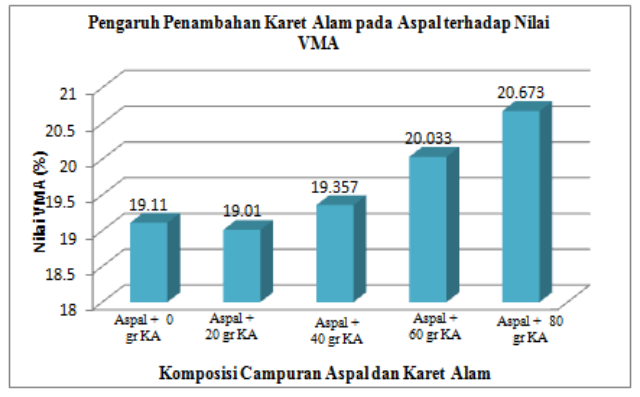

Gambar 4.7 Pengaruh Penambahan Karet Alam pada Aspal terhadap Nilai VMA

Gambar 4.8 menunjukkan bahwa penambahan karet alam pada aspal akan memberikan pengaruh terhadap VFA aspal. Terlihat bahwa nilai VFA aspal dengan penambahan karet alam mengalami peningkatan pada penambahan 20 gr dan 40 gr karet alam, namun ketika penambahan 60 gr dan 80 gr karet alam nilai VMA mengalami penurunan.

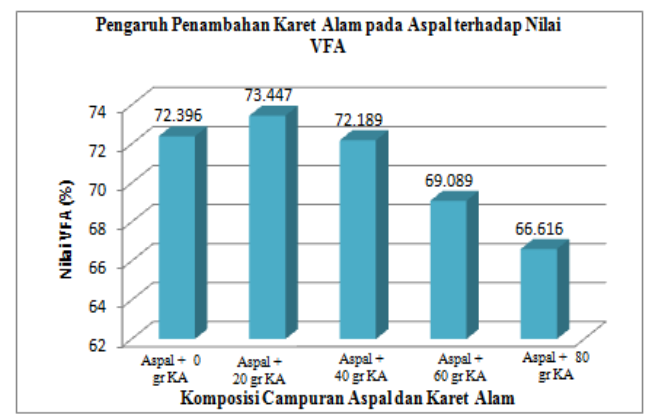

Gambar 4.8 Pengaruh Penambahan Karet Alam pada Aspal terhadap Nilai VFA

\section{PEMBAHASAN}

Dari pembahasan hasil pengujian sifat Marshall diperoleh informasi bahwa penambahan NR sebanyak 20 gr (Aspal + 20 gr NR) menurunkan nilai densitas (kepadatan/berat isi) dan meningkatkan rongga yang terisi aspal (VFA), serta menurunkan rongga dalam campuran (VIM) dan rongga diantara agregat (VMA) jika dibandingkan dengan aspal murni.

Penurunan nilai Densitas dan VIM (rongga dalam campuran) serta VMA (rongga diantara agregat) merupakan kelebihan dalam sistem aspal dengan penambahan 20 gr NR dibandingkan dengan aspal murni. Akan tetapi, Semakin tinggi konsentrasi NR yang ditambahkan dalam sistem aspalNR maka densitas semakin turun, VFA menurun dan VIM serta VMA meningkat. Dari hasil pengujian dan pembahasan juga ditemukan bahwa rongga aspal dengan penambahan $20 \mathrm{gr}$ NR lebih kecil jika dibandingkan dengan aspal murni, namun berbeda halnya dengan penambahan $40 \mathrm{gr}, 60 \mathrm{gr}$, dan 80 gr NR pada aspal yang menyebabkan 
rongga aspal semakin besar dibandingkan dengan aspal murni. Besarnya rongga disebabkan oleh semakin menurunnya berat jenis aspalNR (berat jenis aspal $1 \mathrm{gr} / \mathrm{ml}$ dan berat jenis karet sekitar 0,92 gr/ml). Besarnya rongga ini berdampak pada menurunnya karakteristik keawetan (durabilitas).

\section{KESIMPULAN}

Berdasarkan hasil penelitian yang dilakukan dapat disimpulkan sebagai berikut:

1. Terdapat pengaruh penambahan karet alam pada aspal termodifikasi terhadap karakteristik aspal. Penetrasi aspal dengan spesifikasi aspal pen $80 / 100$ berubah menjadi penetrasi aspal dengan spesifikasi 200/300, nilai titik lembek aspal dan berat jenis aspal menjadi lebih rendah dibandingkan dengan nilai titik lembek aspal murni, penambahan variasi komposisi karet alam mengakibatkan semakin tinggi nilai penurunan berat aspal, dan nilai daktilitas aspal mengalami peningkatan seiring bertambahnya variasi karet alam yang digunakan.

2. Nilai rongga dalam campuran aspal atau VIM mengalami penurunan pada aspal termodifikasi dengan penambahan 1 phr karet alam. Rongga dalam campuran aspal pada penambahan karet alam yakni sebesar 0 phr, 1 phr, 2 phr, 3 phr dan 4 phr yakni $\quad 5,275 \%, \quad 5,048 \%, \quad 5,384 \%$, $6,192 \%$, dan $6,902 \%$. Persyaratan nilai VIM berkisar antara $3-5,5 \%$. Nilai rongga diantara agregat atau VMA mengalami penurunan pada aspal termodifikasi dengan penambahan 1 phr karet alam. Rongga diantara agregat pada penambahan karet alam sebesar $0 \mathrm{phr}, 1 \mathrm{phr}, 2 \mathrm{phr}, 3 \mathrm{phr}$ dan 4 phr yakni $19,110 \%, \quad 19,010 \%$, $19,357 \%$, 20,033\%, dan 20,673\%. Persyaratan nilai VMA minimal $15 \%$ semua sampel memenuhi persyaratan. Nilai rongga terisi aspal atau VFA mengalami peningkatan pada aspal termodifikasi dengan penambahan 1 phr karet alam. Rongga terisi aspal pada penambahan karet alam sebesar 0 phr, 1 phr, 2 phr, 3 phr dan 4 phr yakni $72,396 \%, 73,447 \%, 72.189 \%, 6$

3. 9,089\%, dan 66,616\%. Persyaratan nilai VMA minimal $65 \%$ dan semua sampel memenuhi persyaratan.

\section{PROSPEK}

Untuk prospek ke depan, aspal ini baik digunakan untuk pembuatan campuran aspal pada jembatan.

\section{DAFTAR PUSTAKA}

Chusna, S. F. (2002). Kajian Pembuatan Karet Siklo Berbobot Molekul Rendah. Institut Pertanian Bogor : Bogor.

Fatmawati, S. (2011). Analisa Sifat Bahan Dasar Pembentuk Campuran Aspal Modifikasi Polimer Akibat Perendaman Air Rob.UI :Depok .

Harseno, E dan Daryanto E. (2008), Tinjauan Tinggi Tekanan Air di Bawah Bendung dengan Turap dan Tanpa Turap pada Tanah Berbutir Halus. Majalah Ilmiah UKRIM Edisi2/th XIII. UKRIM : Yogyakarta.

Ing, T.L., Deni S., Ronald S., (2013), Pengaruh Penggunaan PS Ball pada Campuran Beton Aspal. Simposium Nasional RAPI XII-FT UMS.Bandung: Universitas Kristen Maranatha.

Rianung, S. 2007. Kajian Laboratorium Pengaruh Bahan Tambah Gondorukem pada Asphalt Concrete-Binder Course (AC-BC) Tehadap Nilai Propertis Marshall dan Durabilitas, Tesis S-2 Program Pascasarjana Fakultas Teknik Universitas Diponegoro. Semarang. 
Alkhafi Maas Siregar, Winsyahputra Ritonga, Santri Arunika, Analisis Rongga Pada Aspal Iran Pen 80/100 Termodifikasi Dengan Karet Alam (Natural Rubber) Pada Campuran Asphalt Concrete - Wearing Course (AC-WC)

Sari, N.P. (2003). Analisis Kondisi Trotoar dan Kerusakan Perkerasan pada Beberapa Ruas Jalan di Kota Malang. Universitas Negeri Malang : Malang.

Sulistiyatno, A., Mohammad D.S.R.F, Indrasurya B.M, Anak A.K, Mahendra A. M. (2012). Studi
Pengaruh Genangan Air Terhadap Kerusakan Jalan Aspal dan Perencanaan Subdrain untuk Ruas Jl. Rungkut Industri Raya, Jl. Rungkut Kidul Raya, Jl. Jemur Sari, Jl. Nginden Raya, Jl. Manyardan Jl. Mulyosari Raya. Jurnal Teknik Pomits. v1 :1-6. 